\title{
Risti peale kirjutas: Ühel papil oli peni... Eesti loomakalmistukultuurist
}

Marju Torp-Kõivupuu

\begin{abstract}
Teesid
Eestis on lemmikloomade matmiskombestik ja kalmistukultuur suhteliselt uue ja seetõttu harjumatuna tunduva nähtusena pälvinud senini vaid kirjutava meedia tähelepanu. Kirjutise eesmärk ongi anda ülevaade surmakultuuri ühest marginaalsest tahust - lemmikloomade matmiskombestiku ja kalmistukultuuri tekkest 20.-21. sajandi vahetusel Eesti ühiskonnas.

Artiklis käsitletakse põhjalikult kolme praegu Eestis tegutseva (Jõelähtme, Valga, Rakvere) loomakalmistu tegutsemispõhimõtteid, loomade matmiskombestikku, teemakohast usundilist pärimust. Põgusalt peatutakse ka loomade matmiskombestiku vanemal traditsioonil, mis Eesti kultuuriruumis on seotud mõisakultuuriga.

Vaatluse alla tuleb ka lemmikloomakultuur laiemalt: selle tekkepõhjused, seotus modernse tööstusühiskonna ja kristliku kultuuriruumiga, antropomorfismi ilmingud lemmikloomakultuuris jne. Kas nüüdisühiskonnas annab toretsev loomakalmistukultuur tunnistust inimsuhete defitsiidist ja selle tagajärjel tekkinud vajadusest samastada looma inimesega? Hoitavaks näiteks olgu loomaomanike kohta ringlev usundiline pärimust - liigne lemmikule pühendumine võib pärssida inimeste võimalust ise järeltulijaid saada.
\end{abstract}

Märksõnad: antropomorfism, lemmikloomakultuur, loomakalmistud; loomamatused, meediakultuur, rahvausund, surmakultuur.

\section{Sissejuhatuseks}

Tänapäeval ei ärata loomade matused enam erilist imestust, mõned peavad neid isegi tähtsamaks kui inimeste peieid, kirjutas folklorist Sonja Hyttinen 1996. aastal avaldatud artiklis "Mälestus elab!" (Hyttinen 1996: 138).

Eestis on lemmikloomade matmiskombestik ja kalmistukultuur suhteliselt uue ja seetõttu harjumatuna tunduva nähtusena pälvinud senini vaid kirjutava meedia tähelepanu (Olvet 1999; Lepassalu \& Palli 2000; Suviste 2000; Kiiler 2002). Tallinnast paarikümne kilomeetri kaugusele rajati esimene Eesti loomakalmistugi alles 1995. aastal.

http://haldjas.folklore.ee/tagused/nr25/loomakalmistud.pdf 


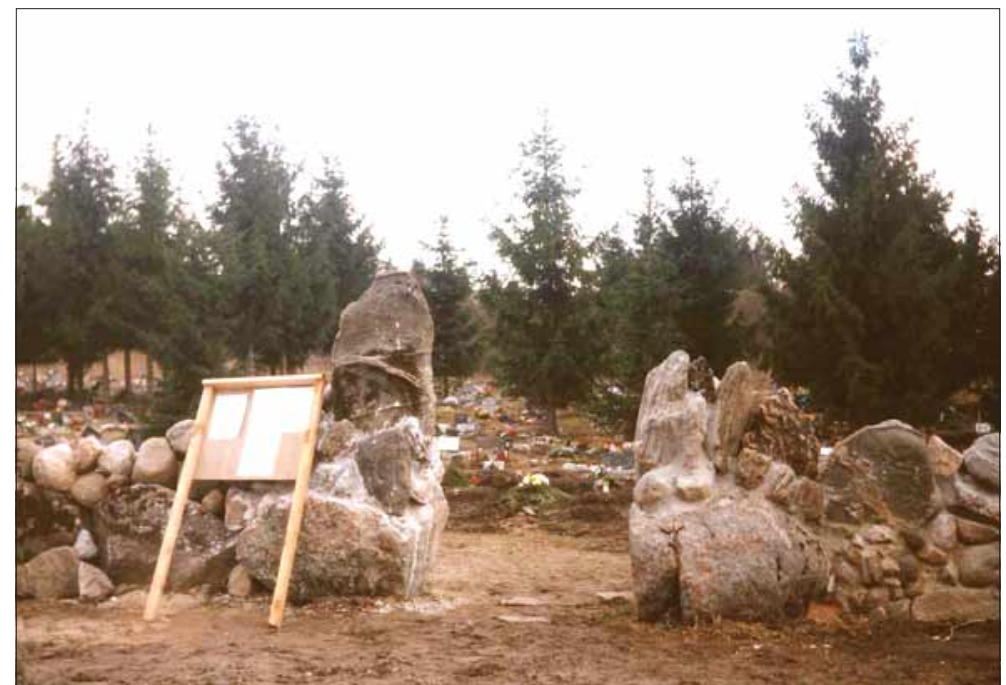

Foto 1. Jõelähtme loomakalmistu. Marju Torp-Kõivupuu foto 2004.

Käeoleva kirjutise eesmärk ongi anda põgus ülevaade surmakultuuri ühest marginaalsest tahust - lemmikloomade matmiskombestiku ja kalmistukultuuri tekkest 20.-21. sajandi vahetusel Eesti ühiskonnas.

Kui külastasin 1990. aastate lõpus esmakordselt Jõelähtme loomakalmistut, tekitas see oma ainulaadsuses mõneti kummastust, et mitte öelda teatavat võõristust. Võib-olla oli selle põhjuseks asjaolu, et ma polnud varem ühelgi loomakalmistul käinud, võib-olla tõsiasi, et kogu selle kalmistu üldilme meenutas liigagi äratuntavalt inimeste endi kalmuaedu. Võimalik, et teatavat võõristust tekitas hoopis sel hetkel endale sügavamalt teadvustamata tõsiasi, et ka lemmikloomakultuur kõigi läänelike suundumustega - nagu palju teisigi Euroopa ja n-ö muu maailma argi- ja kõrgkultuuri ilminguid - on jõudnud Eesti murrangulisse postsotsialistlikku ühiskonda ja püüab siin oma kohta leida.

On ju külaühiskonnas elaval eestlasel läbi aegade olnud koduloomadega eelkõige praktiline suhe: loomade ülesanne on anda liha, piima, villa, teha künnitöid, valvata maja või siis püüda vähemalt hiiri (vt ka Kruus 2004). Ratsionaalne talupojaühiskond pole tundnud lemmikloomakultuuri. Kuigi (kodu)looma on peetud hingeliseks olendiks, asus rahvapärase arusaama kohaselt tema hingeke 
ikkagi hingede "hierarhia" madalamal astmel: inimesel on hing, aga tõpral on toss (vt ka Loorits 1990: 27). Kuigi lastel võisid olla ja olidki oma loomad, otsustasid nende saatuse ikkagi täiskasvanud. Kodulooma "lihtsalt minu omaks olemist" - kui parafraseerida Astrid Lindgreni Pellet raamatust Väike Tjorven, Pootsman ja Mooses (vt eesti keeles Lindgren 1969; 1993; 2000) - talupojakultuur ei aktsepteeri(nud).

Priviligeeritud seisusesse on aga kuulunud aga siinsete mõisnike tõukoerad ja -hobused, kellest mitmeid on kindlasti maetud toredamalt, kui kohalikke vaeseid talupoegi. ERA kogudes leidub arhiivitekste, kust võime lugeda, et baltisaksa parunid, prouad ja preilid on oma suurtsugu lemmikuid matnud mõisaparkidesse ning nii mõnegi neljajalgse sõbra kalmule püstitatud uhke hauasammas on aegade jooksul rikastanud nii mõisnike veidrusi kajastavat kohalikku rahvajutu-traditsiooni kui kujundanud kuni lähiajani ka kohalikku kombestikku:

Kiltsi mõisa parunil oli suur valge koer ja see suri ära ja see on Kiltsi lossi rohuaeda maetud. Suur terav kivi on haua peal mõisa pargis praegugi. Mõni arvab, et mis sammas see on. See pole midagi muud, kui koera haud (RKM II 336, 368 (4) < VäikeMaarja khk, Nõmme k - Mall Hiiemäe < S. Tammistu (1979)).

Tuginedes Ell Vahtramäe suulistele teadetele 2003. aasta ekspeditsioonist Väike-Maarja kihelkonda, on sealsetel noortel olnud tavaks nõukogude ajal ja hiljemgi käia Kiltsi mõisa parunile kuulunud koera hauale pärast kooli lõpuaktust lilli viimas ja küünlaid süütamas.

Neid lemmikloomade hauasambaid, mis on tänaseni ajas vastu pidanud, tutvustatakse nüüdisajal ka kui piirkonna tähelepanuväärseid turismiobjekte ning sellekohast fotodega varustatud infot võib huviline leida maakondade kodulehekülgedelt.

Eesti üks enimtuntud koera haudu asub Läänemaal Koluvere (Kolovere) lossi pargis (vt Läänemaa: http://www./ekaart/Laanemaa. html). Osundatud Interneti-aadressilt leiab koerale püstitatud mälestussambaga e-kaardi, mida võib soovi korral kellelegi edasi postitada.

Viljandimaa turismi-info koduleht annab huvilistele teada, et Kõpu mõisa pargis asub ristidega kivi, mille all on kohaliku mõisniku koera haud (vt lähemalt Viljandimaa Turismiinfokeskus: http://www. viljandimaa.ee/turismiinfo/?mod=9\&sort=1\&id=114\&pknd=). 


\section{Marju Torp-Kõivupuu}

Tallinnas Glehni pargis asuv obelisk tähistab Nikolai von Glehni lemmikhobuse hauda (vt Kuulsaid mõisnikke-http://www.muuseum. harju.ee/Moisad/kuulsaid/kuulsaid_glehn_02.html). Praeguseks on obeliskilt kadunud kirjadega mälestusplaat, nõnda et kultuurilugu mittetundvale inimesele on see tõenäoliselt "tühi" artefakt.

Esimene Eesti Vabariik pidas ideaalseks linnakoduks hooldatud koduaiaga ümbritsetud elamuid - sisuliselt väiketalu vähendatud mudelit. Nõukogude Eesti väikelinnade äärealadel polnud veel 1980. aastatel lehmade, hobuste, lammaste ja sigade pidamine haruldane ja pole seda paiguti tänini. Võib julgelt väita, et teatud osa Eesti väikelinnade elanikest peab ennast küll linlaseks, kuid ei järgi linlikku eluviisi tänini - peab majandusloomi ning kasvatab aiaja köögivilju nii oma pere tarbeks kui ka müügiks.

Suurlinnas elav inimene on rohkemal või vähemal määral võõrandunud nii kultiveerimata kui ka kultiveeritud loodusest ja seal toimuvatest loomulikest protsessidest. Tehiskeskkonnas tekkinud emotsionaalset tühikut aitavad inimestel täita (eksootilised) lem-

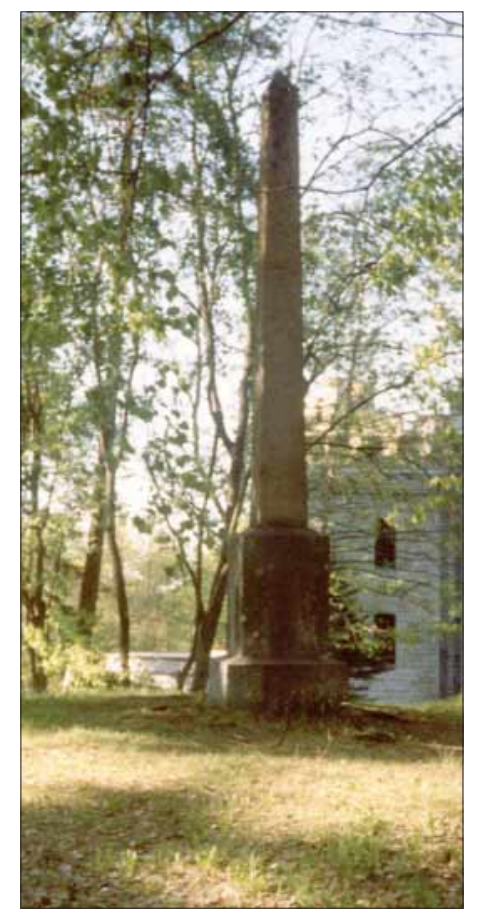

wwww.folkLore.ee/tagused
Foto 2. Nikolai von Glehni hobuse hauaobelisk Tallinnas Nõmmel Glehni pargis. Marju Torp-Kõivupuu foto 2004.

50 
mikloomad ja nendega tegelemine. Vähetähtis pole ka inimsuhete defitsiit: neljajalgne sõber asendab üksildase inimese elus sageli sõpra-seltsilist, teinekord koguni perekonda ja lapsi (vt nt Kruus 2004). Lemmikloomade pidamise jätkuva populaarsuse tõusu seostavad erinevad uurijad ka sündimuse langusega ja nn väikeperede mudeli domineerimisega ühiskonnas (vt ka Hyttinen 1996: 139).

Lemmikute pidamine eeldab samuti keskmisest pisut suuremaid majanduslikke võimalusi: loomatoit, hooldustarbed, veterinaarabi, näitustel esinemine jne - kõik see nõuab omanikult üha suuremaid ja suuremaid kulutusi. Lemmikloomade vajaduste rahuldamiseks töötavad reklaamifirmad, kõnelev, kirjutav ja elektrooniline meedia, loomatoidukontsernid jne.

Nagu tuhandeid aastaid tagasi, näib postmodernses ja tehnokraatlikus linnastunud ühiskonnas elava inimese suhetes lemmikloomadega domineerivat antropomorfism - inimese psüühilisi omadusi omistatakse ka loomadele, sageli neid isegi rõivastatakse nagu inimesi (Hyttinen 1996: 139; Kruus 2004). Arvukalt töötab erinevaid netiportaale, kus lemmikloomaomanikud moodustavad virtuaalseid sõpruskondi (Vesik 2003). Ühel või teisel ajahetkel on "moes" pidada just seda või teist tõugu koera või kassi või siis mõnda muud sootuks eksootilist sõpra jne. Lemmiku valikul pole vähemtähtsad ka usundilised tõekspidamised ja käibetõed, millele toetuvad nii loomaomanikud kui ka nende lähedased. Ka lemmikutele nime(de) andmine on omaette antropomorfistlik ja humanistlik toiming. Prominentsete isikute lemmikloomadest on saanud meediakangelased: näiteks 2002. aasta jaanuari esimestel päevadel edastati erinevate elektrooniliste meediakanalite päevauudistes teade USA ekspresidendi Bill Clintoni labradori retriiveri traagilisest hukust ja see fakt leidis märkimist ka trükiajakirjanduses. Eesti praeguse peaministri Juhan Partsi kass Kiisu-Miisu aga poseerib päevalehtede esikülgedel, peaministri kodulehekülje "privaatsaidil" ja temast on saanud üks võtmefiguure ETV poliitilises pilasarjas Pehmed ja karvased. Seega on lemmikloomadel inimeste elus täita - ja sageli üheaegselt - väga erinevaid rolle: lemmikloom võib samaaegselt olla nii staatussümbol, maja või korteri valvur, lihtsalt seltsiline, saatja jalutuskäikudel jne (Hyttinen 1996: 140).

1995. aastal küsitlesid Tallinnas Lasnamäe Kuristiku gümnaasiumi õpilased oma kooli lähikonna suurte kortermajade elanikke. Nendel küsitlustel selgus muu hulgas, et üheksakorruselistes majades on 500 perekonna kohta 335 koera. Just vene pered peavad 


\section{Marju Torp-Kõivupuu}

suuri tõukoeri ja seda esmajoones selleks, et kompenseerida (kivi)linnaühiskonnas kasvavate laste kasinaid kontakte elusloodusega. Sama küsitluse andmetel võetakse suuri koeri korteritesse ka seetõttu, et nad kaitsevad kodu varaste eest. Märkimisväärne on seegi, et kallite tõukoerte pidamine parandab nende omanike enesehinnangut ja suurendab prestiiži ühiskonnas (Nerman 1998: 402).

Näiteks viiekorruselises 80 korteriga majas, kus Tallinnas elan, on enamikus vene keelt kõnelevates peredes vähemalt üks lemmikloom. Eesti pered peavad korterites lemmikuid vähem või üldse mitte. Tõdesin, et uusasukatena oli meil oluliselt kergem sisse elada, kui venelastest naabrid avastasid, et meil on kass. Vähem kui nädala pärast oli enamikul majarahvast teada, et see on "meie" kass, ning seegi, mis püstakus ja kus korteris on kõutsi kodu. Küsitlesin ise muu hulgas pisteliselt ka Tallinna Pedagoogikaülikooli mitte-eestlastest üliõpilasi lemmikloomade pidamise teemal ja nende sõnutsi on eestlased valdavalt ratsionaalsed, materiaalsed ja tundetud, sest nad ei armasta eriti loomi.

Samas aga ei suuda meie pere Lõuna-Eesti sugulased ja tuttavad mõista, miks peame linnakorteris kassi, ja mis veelgi hullem ostame talle poest spetsiaalset kassitoitu, kassiliiva ja muud vajalikku. Külas on kassi koht jätkuvalt traditsiooniliselt laudas, tema ülesandeks on püüda hiiri ja tuppa teda harilikult ei lasta - erandkorras, eelkõige väga suure pakase puhul võib pigem koer sellise privileegi osaliseks saada.

Seega võib tõdeda, et Eestis - nagu ilmselt kogu maailmas elavate erinevate rahvuste ja erinevate sotsiaalsete rühmade esindajatel on erinevad uskumused, tõekspidamised ja suhtumine (lemmik)loomadesse ning nende pidamisse. Üks osa inimkonnast (peamiselt maarahvas) peab loomi esmajoones praktilise kasu saamise eesmärgil, ülejäänud (kellest enamik elab linnastunud ühiskonnas) vajavad kodulooma kui kadunud sidet elusa loodusega või kui sõpra-seltsilist üksildasse ellu (vt ka Kruus 2004). Lemmikloomakultuur soodustab linnakultuuris ka inimestevahelisi kontakte - inimesed tulevad meelsamini jutlema koera või kassi jalutava juhututtava või isegi võoraga kui päris üksi kõndiva inimesega (Hyttinen 1996: 140).

"Koer on üks integreerumisvahend," mõtiskleb Jõelähtme loomakalmistu peremees Tiit Truumaa. "Kui näiteks pargis jalutab mõni naine koeraga, lähed tema juurde ja hakkad koerast 
rääkima. Ongi suhe loodud. Venelased tulevad kennelliitu, kus enamik on eestlased. Ja suur armastus koera vastu sunnib neid eesti keelt rääkima” (Lepassalu \& Palli 2000: 39).

\section{Surmast ja surmakultuurist. Lemmikloomadega seonduvalt}

Enamik maalapsi on matnud ja matab tänagi kodu- või õueaia nurka hukkunud väikeloomi ja linde, kaunistab nende kääbast lillede või väikese omavalmistatud ristiga. Selles võib näha täiskasvanute maailma mehaanilist jäljendamistarvet, teisalt annab selline matusemäng lapsele esimese kokkupuute surmaga ja aitab mõista elu igavest ringkäiku.

Kui agraar-ja/või külaühiskonnas on suhtumine surma olnud elu mööduvuse paratamatuse tunnetamine, millest kogukond on avatud rituaalide kaudu ühel või teisel viisil osa ja tuge saanud ning mis omakorda on inimesi surmaga lepitanud ja matusetraditsioonidega sidunud (Hyttinen 1996; Torp-Kõivupuu 2003; Pentikäinen 1990), siis 1977. aastal kirjutas Philippe Ariès, et kaasaegses läänemaailma surmakultuuris puudub suremisel koht, see on argipäevast irrutatud ja tabuteema. Suremine seostub arenenud ühiskondades esmajoones meditsiinisüsteemi, haigla, mitmesuguste juriidiliste protseduuridega - argielust irrutatud, võõrandunud maailmaga (Ariès 1977). Sestap on läänemaailmas alustatud taas diskussioone "hea surma" võimalikkusest ka nüüdisühiskonnas - inimese õigusest lahkuda elust kodus, oma lähedaste keskel (Hyttinen 1996: 139). Tänapäeva Eestis tuleb aga jätkuvalt ette erimeelsusi meditsiinitöötajate, surnukuuuri-teenust pakkuvate erafirmade ja lahkunute omaste vahel: lahkunute omaksed tunnetavad, et nende õigusi (hooldus)haiglasse surnud pereliikme inimväärsel kohtlemisel rikutakse (lähedasi ei teavitata omakse surmast piisavalt kiiresti; lähedastel ei lubata ise surnut pesta, riietada jne, surnukeha hoidmise eest nõutakse suhteliselt suuri summasid jne) (Päärt 2004: 9).

(Lemmik)looma surm ei näi arenenud lääneühiskonnas olevat nii hirmutav ja traagiline, kui seda on inimese surm. Kui lemmik sureb, võidakse küll nutta, kurvastada, kuid mõne aja möödudes on võimalik endale ikkagi soetada uus neljajalgne sõber (Hyttinen 1996: 139). 


\section{Marju Torp-Kõivupuu}

Loomadele mõeldud kalmistuid on möödunud sajandi lõpukümnenditel (suur)linnastunud tööstuslikus lääneühiskonnas tekkinud üha enam ja enam (Hyttinen 1996; Wolf 1989; Wiedenmann 1993; Stark 1993). Ka Eestis tekkis enam-vähem samal perioodil vajadus lemmikloomade matmispaikade järele: magalarajoonides on suhteliselt lühikese elueaga väikelooma või -linnugi (hamstri, koduroti, viirpapagoi vm) matmine probleemiks, sest enamik lemmikloomapidajaid ei pea eetiliseks visata loomakese surnukeha lihtsalt prügikasti (vt ka Mikkor 2000: 152-153).

Kui suvisel ajal on võimalik loomakese laip matta kas või näiteks maja taha haljasalale, siis mida teha talvel, kui maapind on külmunud? Oma kogemustest 1990. aastate alguse Tartu-päevilt mäletan, et poja talvel surnud hamstrit hoidsin paberkotti pakituna puukuuris kevadeni ja kui maapind oli piisavalt sulanud, sai loomakene tagahoovis kasvava paju alla viisipäraselt maha maetud. Keskküttega paneelmajade elanikel puukuure paraku pole ja väikeloomaomanikel tuleb lemmiku surma korral leida muid lahendusi. Üks võimalusi on näiteks hoida surnukeha kevade saabumiseni sügavkülmikus (vt Mikkor 2000: 152-153, 157), et siis leida sobiv matmispaik:

1980. aastatel suri mu tütre Tallinna sõbrannal mingi puurilind, kanaarilind vist. Suri keset talve, nii et teda kohe kuidagi matta ei saanud. Sellegi linnukese surnukeha hoiti mitu kuud külmkapi sügavkülmutuses ja maeti kevadel Rahumäele perekonna hauaplatsile.

Suurte majade akende alla põõsaste vahele või rõdu alla väikeloomade matmisest olen ka kuulnud. Paari aasta eest suri mu väikestel sõbrannadel hamster. [---] Loomake maeti suure viiekorruselise maja taha koduakna all. Lapsed igatahes põletasid seal haual mitu päeva küünlaid ja panid lilli. Ja muidugi koos sõpradega (suuline teade Marju Torp-Kõivupuule < naine, s 1955 (mai 2004)).

\section{Ülevaade Eesti loomakalmistutest}

Eesti esimene lemmikloomade kalmistu rajati 1995. aastal Tallinnast paarikümne kilomeetri kaugusele Maardu külje alla Jõelähtme valda. Mõtte algatas 1994. aastal omaaegse Kostivere sovhoosi 


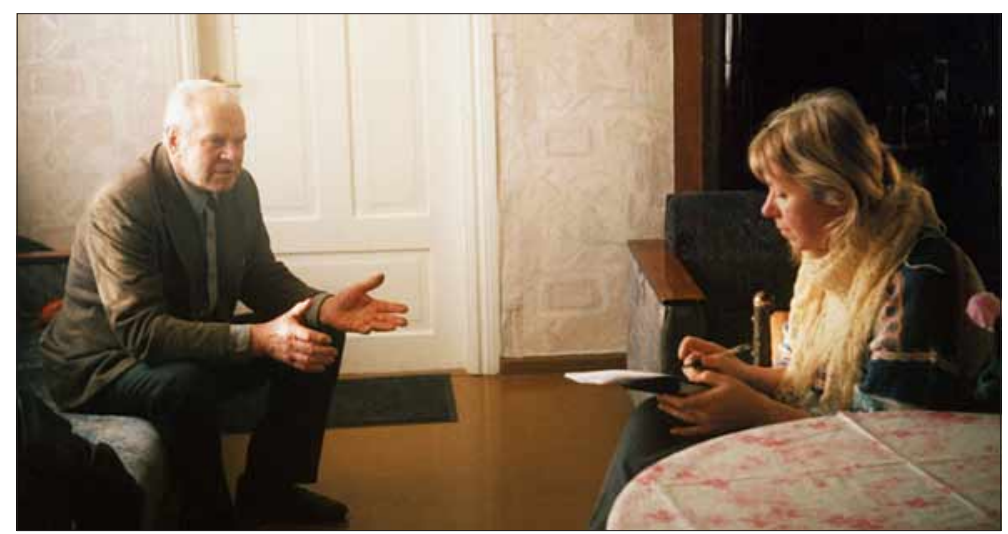

Foto 3. Marju Torp-Kõivupuu küsitleb Tiit Truumaad. Tiit Torbi foto 2002.

veterinaararst Enno Kosk, kelle idee pärineb Kanadast. Kalmistut aitas rajada Harju II Lions Club ja selle valdajaks on pensionil veterinaararst Tiit Truumaa. 1936. aastal sealsamas Maardu mõisas sündinud mehe talu maadel umbes 4000 ruutmeetri suurune kalmistu ka paikneb. Tänaseks on ametlikke väikeloomade matmispaiku rajatud teistessegi linnadesse, näiteks Rakverre ja Valka, ning T. Truumaa sõnul on käidud kalmistuga tutvumas ja eeskuju võtmas ka väljastpoolt Eestit - näiteks Riiast.

Kalmistu peremehe sõnutsi ajendas teda loomakalmistut rajama inimühiskonnas üha sagenev julmus ja hoolimatus: aastaid tagasi leidnud seenelised Maardu karjäärist valgetesse linadesse mässitud tundmatute inimeste laibad, kes olid uputatud kui kassipojad, kivid jalgade külge seotud (vt ka Lepassalu \& Palli 2000: 3940). "Kui inimesi aetakse auku nagu loomi, siis loomi tuleb matta nagu inimesi," loodab T. Truumaa ja usub, et inimesed muutuvad loomi inimlikult mattes ka ise inimlikumaks.

Valga loomakalmistu on rajatud Valga linnavalitsuse eestvõttel linna maadele 2000. aastal. See on esimene omataoliste hulgas, mida finantseerib täielikult linn. Valga veterinaarameti peaveterinaar Jaan Luht tõdes, et kui inimestelt selle teenuse eest veel ka tasu küsida, loobutakse loomakalmistu kasutamisest, sest kohalikul rahval on niigi vähe raha. Kalmistu leidmise hõlbustamiseks on linna üles pandud ka vastavad teeviidad (vt foto 5). Loomakalmistule on rajatud moodne riistakuur (vt foto 4), kust võib soovi korral võtta matmiseks vajalikke abivahendeid (labidaid, kärusid jne). Kui 


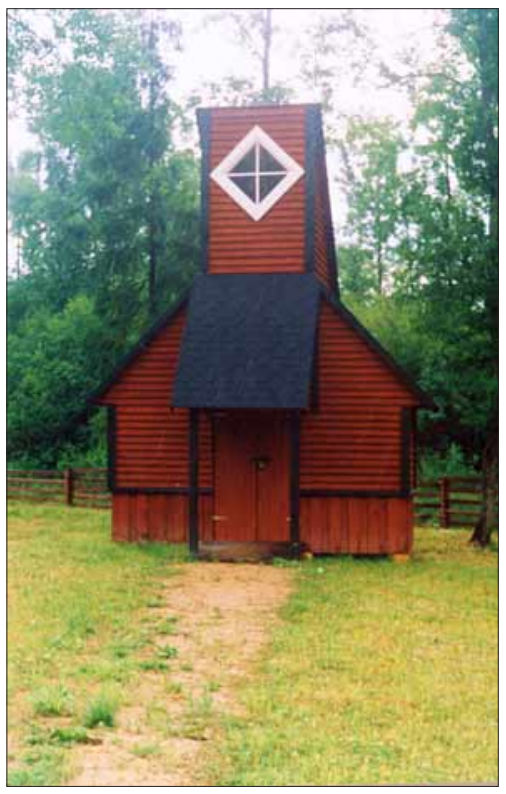

Foto 4. Ajakohane tööriistakuur Valga loomakalmistul. Marju TorpKõivupuu foto 2002.

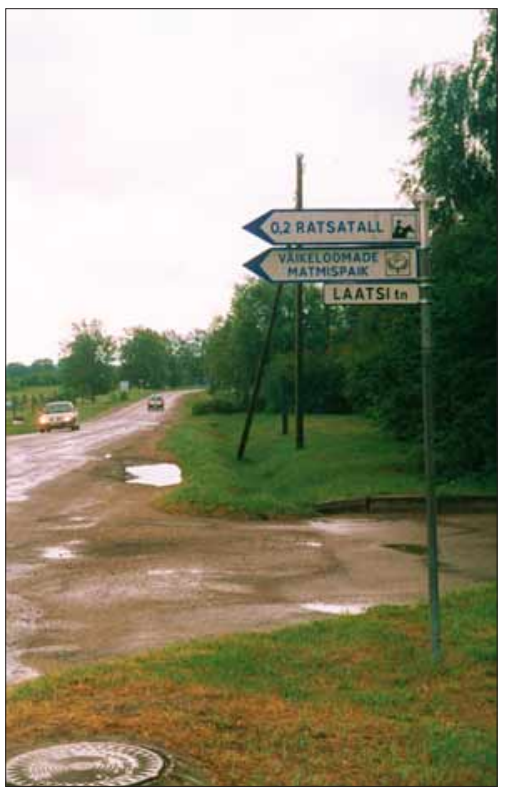

Foto 5. Väikeloomade matmispaika suunav teeviit Valgas Võru tänaval. Marju Torp-Kõivupuu foto 2002.

omanik otsustab individuaalse hauaplatsi kasuks, tuleb tal loomale ise haud kaevata ja ise ka loom matta. Kalmistu tagaosas on ühishauad, kuhu maetakse koerad-kassid segiläbi. Ühishauda maetakse ka varjupaigas hukatud loomad. Varjupaigas hoitakse loomi linna kulul kaks nädalat.

J. Luha sõnul tekkis loomakalmistu järele puhtpraktiline vajadus - surnud loomi visati prügikastidesse või kuhu juhtus. Kuigi Valga on tüüpiline eramurohke väikelinn, pole ka siin korterelamutes elavatel inimestel alati võimalust oma lemmiklooma matta - igaühel pole suvilat ega isiklikku maalappi. Ning ega eramute omanikudki saa enda ja sõprade-tuttavate lemmikloomi lõputult aiamaale matta.

Rakvere lemmikloomade matmispaik rajati mõned aastad tagasi Kullaarusse kohalike linnavõimude ja kohaliku koerte varjupaiga juhataja Elfriede Sillapere eestvõtmisel, kellele oli vastuvõeta- 
matu, et magama pandud või surnud lemmikloomad viidi prügimäele, kus need sageli päevi vedelesid, enne kui buldooseriga muu prügi hulka lükati (http://www.eau.ee/ astan/varjup.htm\#varjup viimati täiendatud 26. märtsil 2004).

Loomakalmistuks eraldatud ja võrkaiaga piiratud lage ala on umbes keskmise nõukogudeaegse elamukrundi suurune. Eeldatav teenuskulu (uinutamine, transport, mälestustahvel jms) ühe looma matmiseks võib ulatuda 200-300, harukordadel ka kuni 600 kroonini. Odavam on matmine ühishauda. Loomakalmistu rajamise idee realiseerimine (maa erastamine, load muinsus- ja tervisekaitselt ning Eesti Energialt jne) läks Rakvere linnavalitsusele väidetavalt maksma ligikaudu 40000 krooni. Loomakalmistut finantseeritakse koos koerte varjupaigaga linna eelarvest (http:// www.eau.ee/ astan/varjup.htm\#varjup - viimati täiendatud 26. märtsil 2004).

\section{Kes loomakalmistutel puhkavad?}

Liigilise kuuluvuse järgi on Jõelähtme loomakalmistule enim maetud koeri (300-400) ja kasse (150-200). Väike- ja eksootilistest loomadest nimetab kalmistuperemees kilpkonni, merisigu, papagoid, kääbusküülikut, rotte, hiiri ja kõige haruldasemana boamadu. Kõige vanem loom, kes kalmistul puhkab, on 19-aastane siiami kass, ja kõige noorem poolepäevane kassipoeg. Kilpkonna mattes ei saanud kalmistuperemees arugi, kas loom oli surnud või oli tal vaid raskusi talveunest ärkamisega. See kilpkonn elas 16aastaseks (Lepassalu \& Palli 2000: 38).

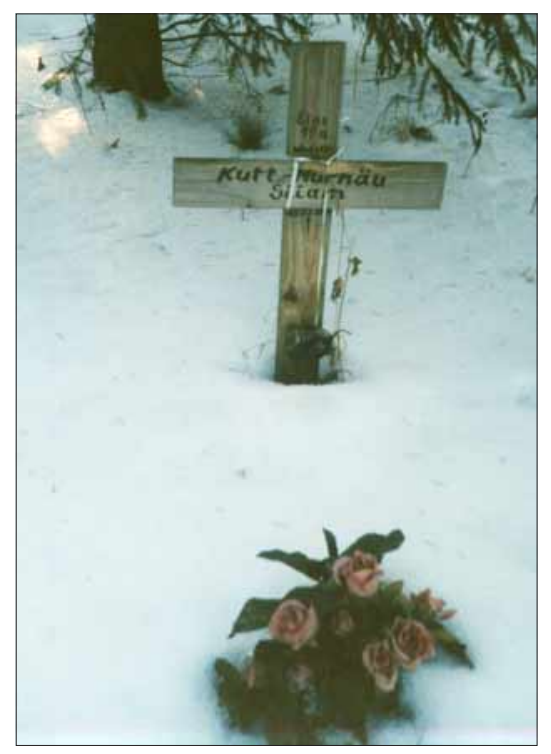

Foto 6. 19-aastase siiami kassi haud Jõelähtme loomakalmistul. Marju Torp-Kõivupuu foto 2002. 


\section{Marju Torp-Kõivupuu}

Ruumi on! Hobusearmastus on meil alles hiljuti tekkinud, jõuavad veel tulla (Lepassalu \& Palli 2000: 40).

Jõelähtme loomakalmistul võib ka täheldada matuseplatside rühmitumist liigilise kuuluvuse järgi: väikeloomadel oma piirkond, koertel ja kassidel oma sektorid.

Valga loomakalmistul oli 9. aprilliks 2004 vähemalt kuus hauda, neist paaril puudusid hauatähised. Kõige uhkemalt tähistatud haud kuulub kaukaasia lambakoerale:

Selle koera peksid joodikud surnuks. Hundikoera moodi koera haua peal kasvab puu. See loom suri vanadusse. Üks tähistamata haud kuulub dobermannile. Selle kohta ei tea, miks või millesse ta suri (Endel Rebane Marju Torp-Kõivupuule 2. juulil 2002).

Kalmistu ilmselt ainsa, kollakaspunast karva angoora kassi kalmu ehteks on toodud kaks kassi kasukaga samas toonis kunstroosi ning

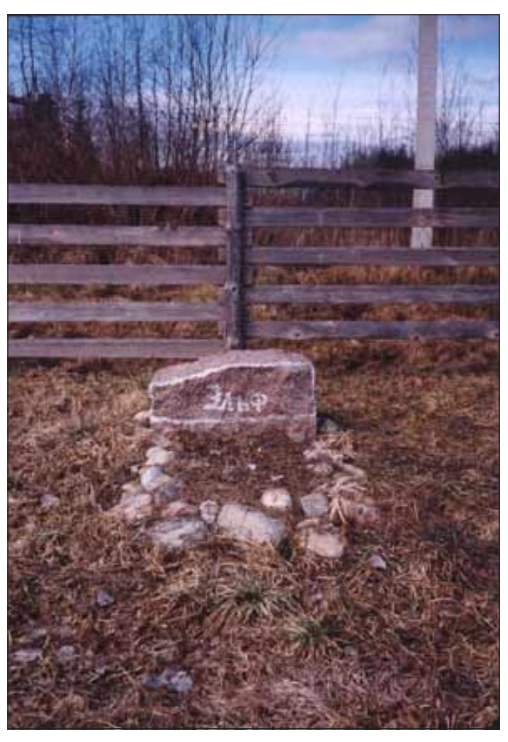

Foto 7. Kaukaasia lambakoera haud Valga loomakalmistul. Marju Torp-Kõivupuu foto 2004.

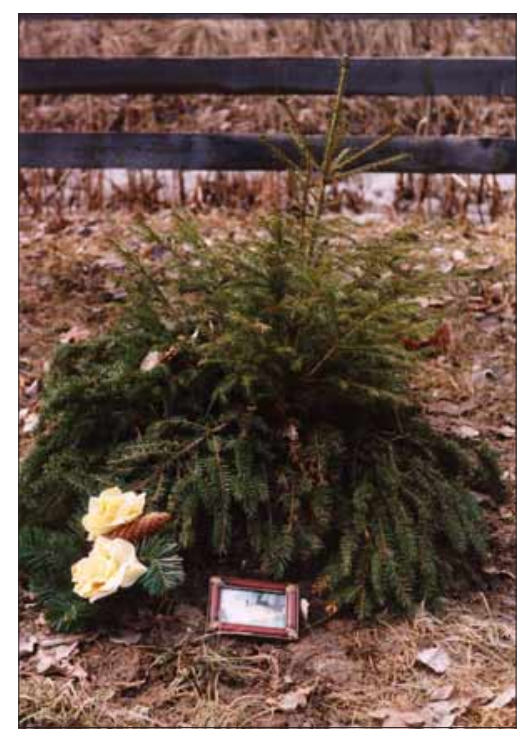

Foto 8. Punast karva angoora kassi haud Valga loomakalmistul. Marju Torp-Kõivupuu foto 2004. 


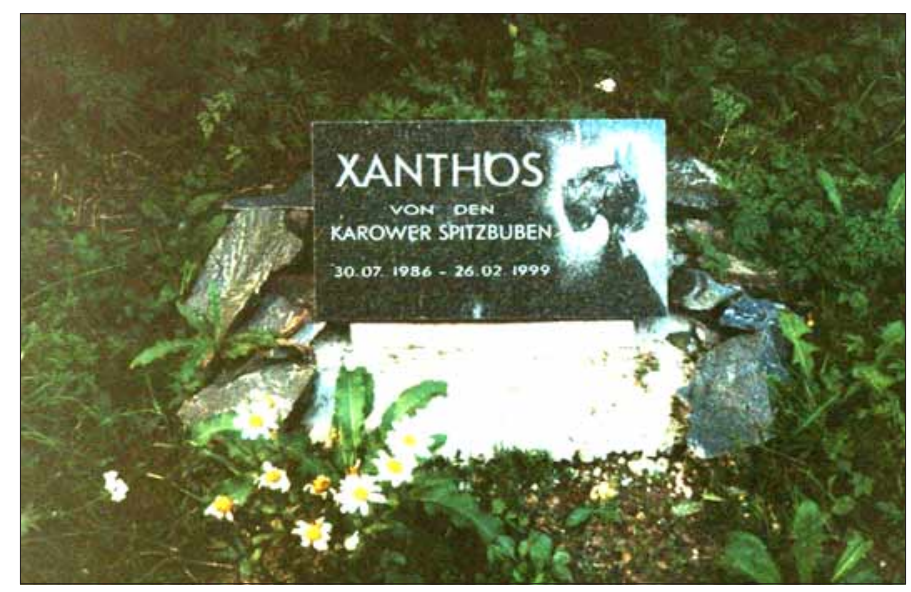

Foto 9. Maineka sugupuuga terjeri haud Jõelähtme loomakalmistul. Marju Torp-Kõivupuu foto 2001.

klaasi alla raamitud värvifoto (vt foto 8). Ühele pisikesele püsivalt tähistamata hauale oli toodud viimaste jõulude aegu tillukene ehitud kuusepuu.

Ka Rakvere lemmikloomade kalmistule on maetud kõrvuti täiesti tavalisi krantse ja mitukümmend tuhat krooni maksvaid paberitega tõukoeri, neist eksootilisim ülihinnaline mastif Joras Ciywind de Mingowal. Lisaks koertele ja kassidele on Rakvere kalmistul oma hauaplats ka ühel toonekurel ja papagoil (Kiiler 2002).

\section{Kes lemmikuid matavad}

Loomaomanike rahvusliku kuuluvuse järgi on Jõelähtme loomakalmistule oma lemmikuid matnud suures osas mitte-eestlased: kirillitsas hauakirjad näivad visuaalsel vaatlemisel olevat ülekaalus. Loomaomanikest domineerivadki kalmistu peremehe sõnul esmajoones Tallinna vene keelt kõnelevad elanikud, kuid oma neljajalgseid sõpru on kalmistule toonud ka Ida- ja Lääne-Virumaa, eelkõige Kohtla-Järve asukad. Jõelähtme kalmistule on oma lemmikloomad matnud ka Taani, Norra ja Vene saatkondade esindajad. Väidetavalt puuduvat Norras loomakalmistute traditsioon, selle olemasolu Eestis olnud saatkonnatöötajatele meeldivaks üllatuseks. 


\section{Marju Torp-Kõivupuu}

Valga ja Rakvere loomakalmistutele matavad oma neljajalgseid sõpru väidetavalt peamiselt eestlased, kuid et need on alles väga värsked ja väikesed matmispaigad, pole vähese materjali põhjal võimalik teha esialgu suuremaid üldistusi. Ka Rakvere, samuti nagu Jõelähtmegi loomakalmistule tuuakse matmiseks loomi ka väljastpoolt maakonda, peamiselt Ida- ja Lääne-Virumaalt: Tapalt, Rakkest, Kuusalust, Kiviõlist, Tamsalust, isegi Jõgevalt jne (Kiiler 2002).

\section{Kalmistute üldilmest}

Jõelähtme loomakalmistu üldilme meenutab esmapilgul tüüpilist metsakalmistut: väikesi hauaplatse ümbritsevad peaasjalikult kuused, kalmistule viib pajuallee ja kalmistu ühes nurgas kasvavad saarepuud. Hauaplatsidele on omanikud istutanud nii leht- kui ka oksapuude dekoratiivvorme.

Vastavalt omaniku materiaalsetele võimalustele on kujundatud ka lemmikloomade hauakivid. Luksulikemad, T. Truumaa sõnul kuni 9000 krooni maksvad, on mustast marmorist sambad, kuhu on graveeritud lemmiku pilt, tema nimi, sünni- ja surmadaatumid ning harvem järelhüüe (Sind igavesti armastama jäädes; Me ei unusta sind

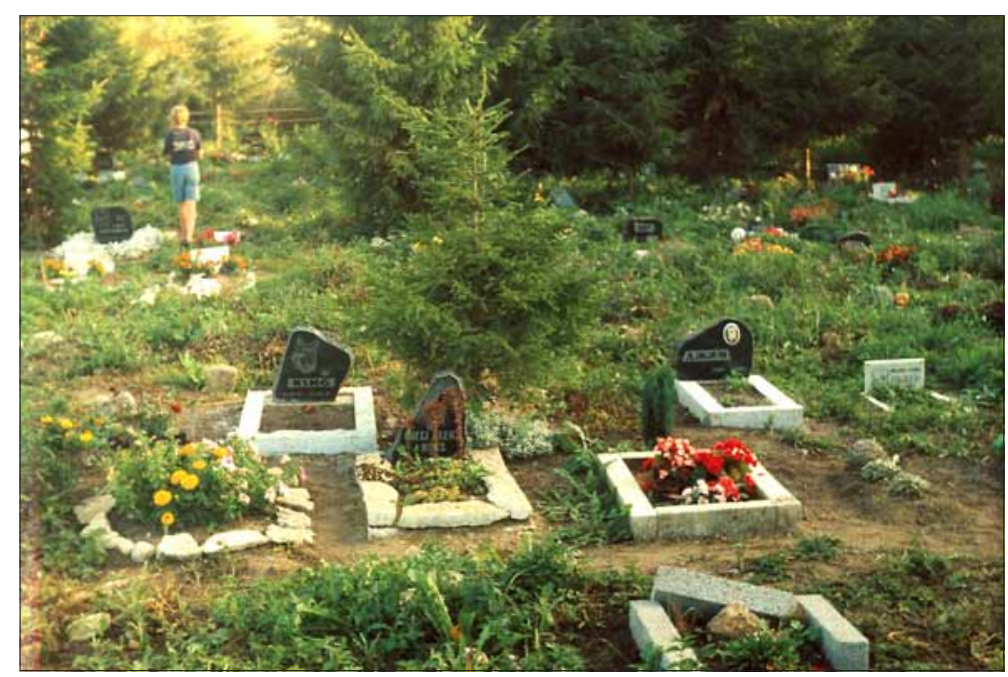

Foto 10. Jõelähtme loomakalmistu. Marju Torp-Kõivupuu foto 2001. 
Marju Torp-Kõivupuu
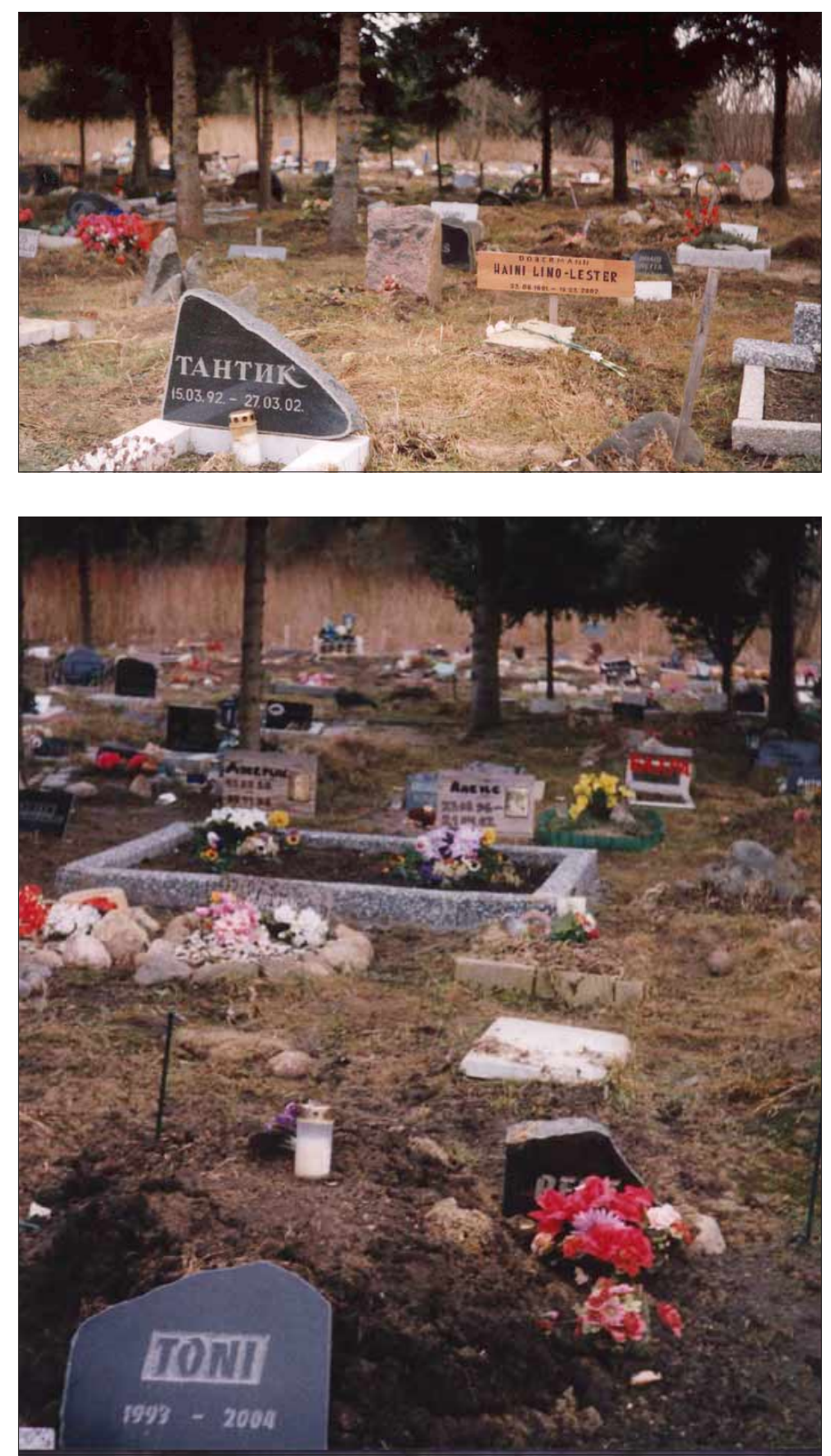

Fotod 11 ja 12. Jõelähtme loomakalmistu nn uus osa. Marju Torp-Kõivupuu fotod 2004. 
Marju Torp-Kõivupuu

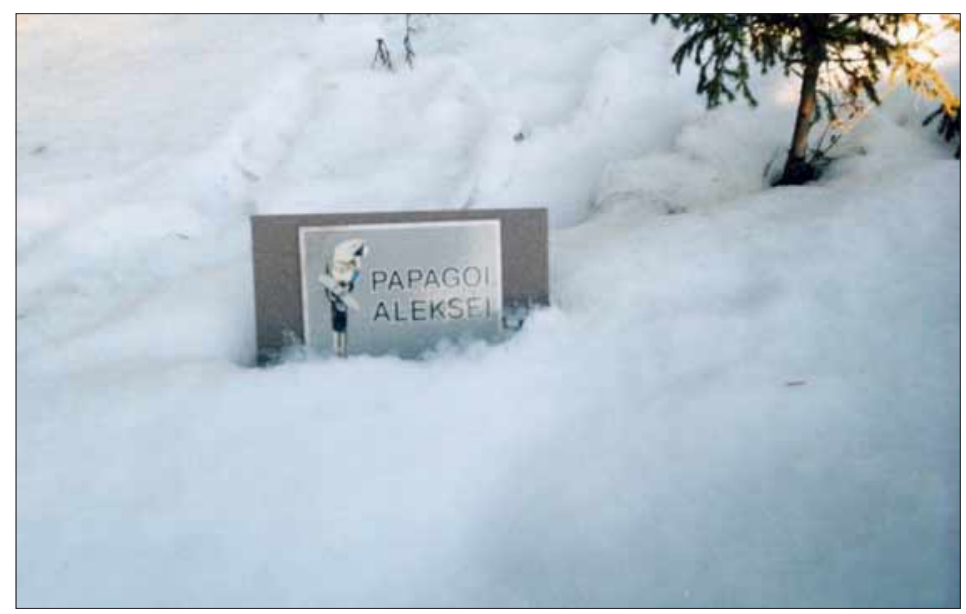

Foto 13. Papagoi haud Jõelähtme loomakalmistul. Marju Torp-Kõivupuu foto 2002.

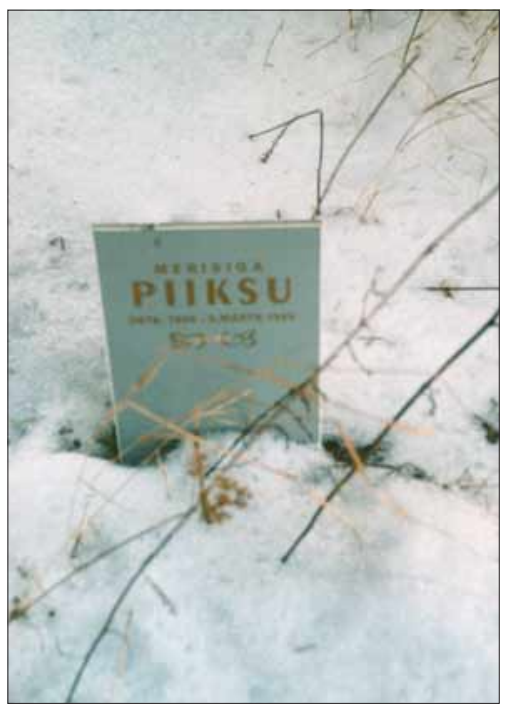

Foto 14. Merisea haud Jõelähtme loomakalmistul. Marju Torp-Kõivupuu foto 2002.

www. folkLore.ee/tagused

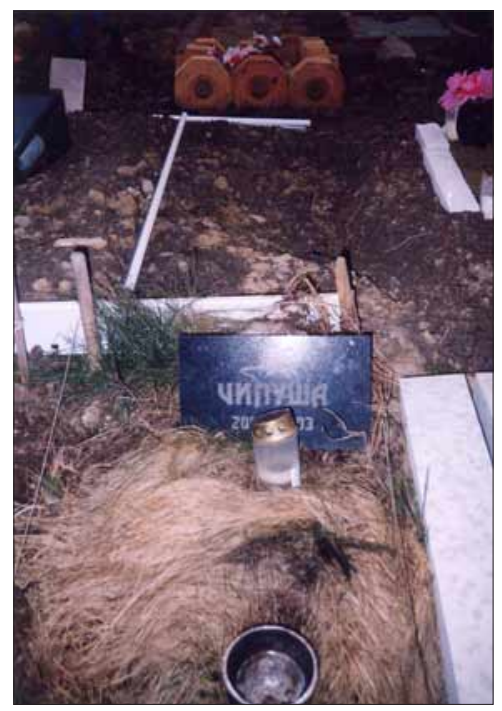

Foto 15. Roti haud Jõelähtme loomakalmistul. Marju Torp-Kõivupuu foto 2004. 
iialgi; Leiname ustavat sõpra jne). Eranditult aga puudub igasugune teave omanike kohta, neid oskab nimetada ainult kalmistu peremees. Tema sõnutsi puhkab kalmistul mitmete Eesti avaliku elu tegelaste lemmikuid, näiteks Alo Põldmäe koer, Ago-Endrik Kerge ja Elle Kulli laste kääbusküülikjne. Kuulsaimaks maetuks arvab peremees Moskva tsirkuses ja vene mängufilmides esinenud puudli.

Valga lemmikloomade matmispaik on esialgu veel lagedavõitu ja märkimisväärselt tagasihoidlikum, kuid sellest näib kujunevat Eesti kalmistukultuurile iseloomulik isikupäraselt kujundatud individuaalhaudadega metsakalmistu tüüpi rahula.

Rakvere loomakalmistu on nn Ameerika tüüpi matmispaik, kus murust paistavad välja korralikult ritta seatud ühesugused hauaplaadid (Kiiler 2002).

Vastavalt omaniku soovile valmistavad lemmikloomadele mõeldud hauakive Jõelähtme kalmistu tarbeks Tallinna Liiva kalmistu kiviraidurid, kelle sõnutsi olevat kõige raskem kivisse jäädvustada pärsia kasside portreid viimaste isikupäratu näo ja olematu miimika tõttu. Jõelähtmes on levinud kombeks ka loomade fotode kinnitamine hauakividele. Mõnede lemmikute haudu ehivad tahumata looduslikud kivid, mis on tulnud välja hauda kaevates ja mille struktuurist võib hea fantaasia korral väidetavalt leida surnud looma või

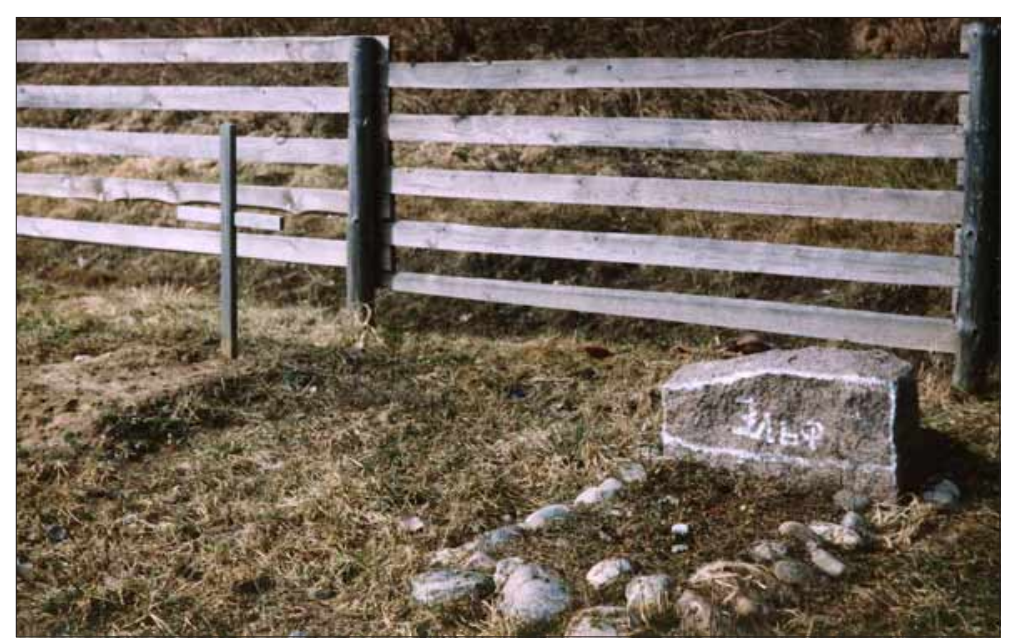

Foto 16. Lemmikute hauakünkad Valga loomakalmistul. Marju TorpKõivupuu foto 2004. 


\section{Marju Torp-Kõivupuu}

tema elukeskkonda iseloomustavaid sümboleid: tigeda terjeri hauast leitud madude kujutisega graniiditükk, üksiku vanaproua koera hauakivi meenutab teatava nurga alt leinavat naist jne. Oma lemmikule on võimalik mälestustahvel tellida ka Rakvere loomakalmistu teenuste kasutajal (Kiiler 2002).

On tähelepanuväärne, et paljude loomade haudu ehivad ristid või leiab ristimärgi hauakivisse graveerituna. Näiteks Valga loomakalmistule on ühe koera hauale pandud must puust rist (vt foto 16), mis näib olevat soetatud inimestele mõeldud matusetarvete büroost. Jõelähtme loomakalmistu ühe lemmiku haual asub puust $\mathrm{nn}$ vene rist (vt foto 17 ).

Ristimärk on püha ja müstiline sümbol, mis on tuttav juba esiajaloost. Täiesti uue tähenduse andis ristimärgile kristlus, kuid kristlik ristimärgisümboolika sisaldab ka kõiki risti ristiusueelseid tähendusi (Jobes 1962). Jõelähtme loomakalmistu peremehe T. Truu-

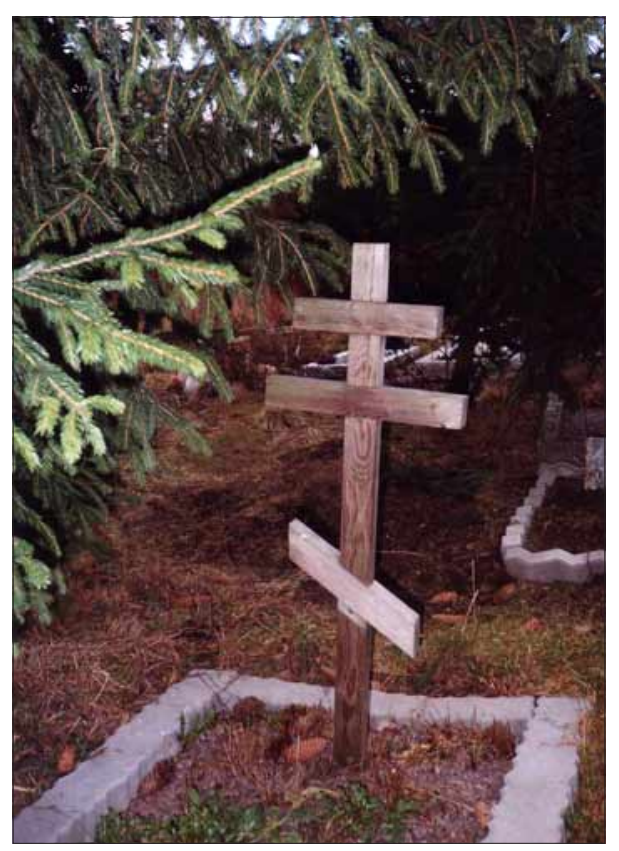

Foto 17. Nn vene rist lemmiklooma haual. Marju Torp-Kõivupuu foto 2004. 

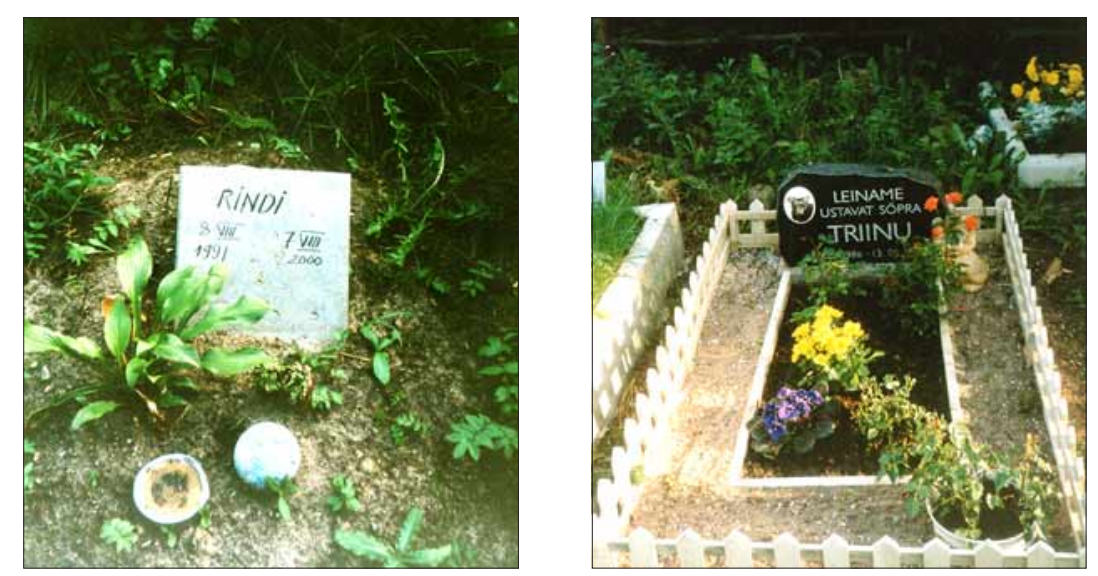

Fotod 18ja 19. Loomaomanike ebavõrdsed majanduslikud võimalused kajastuvad ilmekalt kahe koera hauaplatsi kujunduses Jõelähtme loomakalmistul. Marju Torp-Kõivupuu fotod 2001.

maa sõnutsi tulevat aga kirikuõpetajate väiteil ette koguni lemmikloomade ristimist, mis andvatki õiguse lemmikute haudadel kristlikku sümboolikat (antud juhul siis ristimärki) kasutada (Tiit Truumaa Marju Torp-Kõivupuule 2001).

Helsingi loomakalmistu populaarseim kristlik sümbol on väidetavalt inglikujutis ning Taaveti tähte ja ristimärki soomlaste loomakalmistukultuuris üldiselt ei kasutata (Hyttinen 1996: 151). 2004. aasta lihevõtete aegu Jõelähtme loomakalmistut külastades tõdesin, et nüüdseks on inglikujukesi hauakaunistustena hakanud kasutama ka Eestimaa lemmikloomapidajad ning Jõelähtme loomakalmistu kasutajatele kirjapandud soovitustes seisis muu hulgas märkus, et ristimärgi kasutamine hauatähisena ei ole Jõelähtme loomakalmistul soovitatav.

Loomaomanike materiaalsest ebavõrdsusest, aga ka maitsest ja tõekspidamistest annab tunnistust ka hauaplatside üldilme asisemad on saanud lubada luksusplatsipiiret (valatud ranti või metallaeda), kääpale on istutatud rikkalikult dekoratiivlilli ja üksikutel juhtudel on hauaplatsile paigaldatud isegi istepink. Tagasihoidlikuma rahakotiga omanike lemmiku kääpal kasvavad poollooduslikud ilutaimed ja ilmetule betoonplaadile või puutahvlikesele - kui sedagi - on käsitsi püüdlikult kirjutatud lemmiku nimi ja eluaastad. 
Marju Torp-Kõivupuu

\section{Mõnda lemmikloomade matmiskombestikust}

Lemmikloomade matmiskombestik näib olevat tihedalt seotud loomaomanike rahvusliku ja usulise kuuluvusega ning kopeerib üldjoontes vastava etnilise rühma traditsioonilist matmiskombestikku. Lemmikloomakultuuri lahutamatuks osaks on eutanaasia. Veterinaararstist Jõelähtme loomakalmistu peremees Tiit Truumaa on osutanud ja osutab vastavat teenust, sest peab seda inimlikuks: kui loomale on elu muutunud piinavaks, on humaansem lõpetada tema vaevad süstiga (Suviste 2000).

T. Truumaalt saab loomaomanik soovi korral tellida mälestustseremoonia. Selleks on eraldi ruum, kus musta linaga kaetud lauale asetatud kirstu kõrval süüdatakse küünal ja peetakse väike kõne. Kord tulnud tal suupillil isegi leinaviise mängida.

Papist kirste sai osta kohapeal. Neid valmistas lähedal asuv pappkaste ja muud kartongtaarat tootev väikeettevõte. See aga kolis Tallinnasse ja nüüd maetakse paljud lemmikud maha "nagu jumal nad lõi”. Maausule lähedaste vaadetega T. Truumaa peabki ise õigeks, et lemmikloom saab maetud kas sootuks ilma "puusärgita" või võimalikult keskkonnasõbralikus sargas, mis looduses kergesti laguneb (vt ka Lepassalu \& Palli 2000: 40).

Lisaks loodussõbraliku puusärgi propageerimisele peab T. Truumaa õigeks, et loomad maetakse nn looteasendis (nii kerratõmbunult kui vähegi võimalik), ja ta põhjendab oma seisukohta sellega, et ka imetaja loode areneb emaüsas nii "kokkupakituna" kui vähegi võimalik, sest siis võtab ta vähe ruumi. Väljasirutatult maetud loomad võtavad ka kalmistul asjatult palju ruumi ning nende kääpad ei tasandu piisavalt kiiresti, pigem vastupidi - kippuvat n-ö maa seest välja kerkima. See aga pole omakorda looduses toimuvaid loomulikke kõdunemisprotsesse arvestades kuigi mõistlik ega esteetilinegi. Krematooriumiahju ostmine on seni käinud loomakalmistu haldajatele üle jõu ja ilmselt ei tasuks see ennast ka ära, arvab T. Truumaa.

Väidetavalt on omanikud soovinud oma lemmikuid matta ka kilekottides ja tammekirstudes. Üks perenaine ütles, et kui tema isa ja ema on saanud tammepuust kirstu, siis miks ei peaks seda saama koer, kes oli samavõrd pereliige, meenutab T. Truumaa üht värvikat näidet, kus lemmiklooma positsioon perekonnas on olnud võrdsustatud omaniku vanemate positsiooniga. Mustade maikade, 
kuldkettide ja nahktagidega tursked vene mehed eelistavat oma koeri matta nahktagisse keeratuna (Olvet 1999).

Lemmiklooma matustele tuldavat sageli koos mitme autotäie rahvaga: sugulaste, sõprade, tuttavate ja töökaaslastega. Venelastel olevat T. Truumaa sõnul kombeks suviti pärast matusetalitust kalmistu lähedal peiesööminguga piknik maha pidada:

Tänagi toodi Kohtla-Järvelt siia üks peni, no lasti pisike pisar ning väike rumka käis ringi. Nagu see kombeks on (Lepassalu \& Palli 2000: 38).

Eestlast seevastu iseloomustavat individuaalsus - pärast leinatalituse lõppu käivat omanik mornilt üksinda, pea maas, ega soovivat suhelda. Lemmikute värsked kalmud ehitakse - nagu inimestegi puhul - vastavalt võimalustele rohkem või vähem rikkalikult lillede ja pärgadega.

Kui mõned lemmikloomapidajad peavad vajalikuks surnud sõbrakesele ka pisut toidukraami teispoolsusesse ühes panna (Mikkor 2000: 153), siis T. Truumaa sõnul pole see Jõelähtme kalmistu kasutajatel kombeks. Küll aga võib kääbastelt rikkalikult leida ohverdamiskombestiku jälgi. Hauaplatsidele on jäetud koerte ja kasside jalutusrih$\mathrm{mu}$, nende lemmiklelusid, toidunõusid ja muid omanikule emotsionaalse väärtusega pisiesemeid, mis kuidagiviisi lahkunud lemmikuga ühenduses.

Kalendritähtpäevadel, eriti jõulude ajal, on kombeks süüdata kalmudel küünlaid. Mõned on kalmistule toonud isegi tibatillukese jõulukuuse ja riputanud sellele ehted külge või ehtinud kääpa kõrval kasvava kuuse oksi. Lemmiklooma haudadele viiakse ka toidukraami - jõulude ja uusaasta paiku komme, pi-

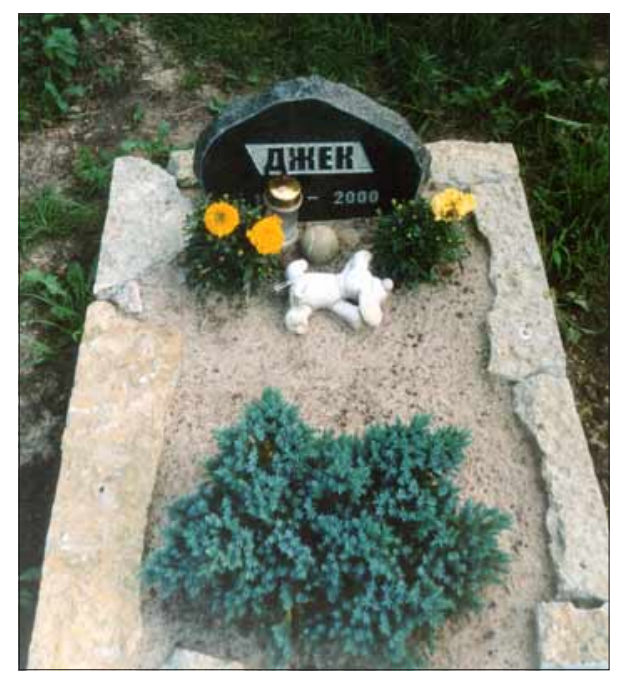

Foto 20. Lemmiklooma hauale on jäetud ka tema lemmikmänguasjad. Marju TorpKõivupuu foto 2001. 

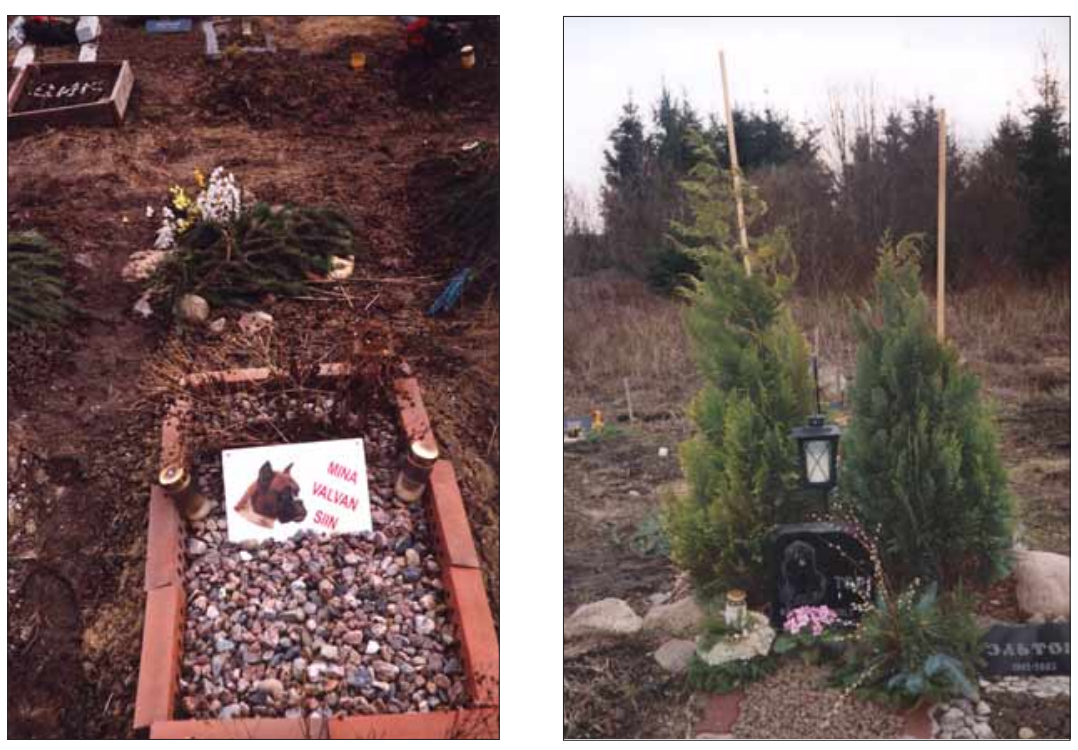

Fotod 21 ja 22. Lemmiklelud ja tähtpäevakaunistused neljajalgsete sõprade haual Jõelähtme loomakalmistul. Marju Torp-Kõivupuu fotod 2004.

parkooke, konditükke, loomade lemmiktoitu jms. Õigeusklikud toovat värvitud mune lihavõttepühadel ka "väiksemate vendade" haudadele. Venelastel polevat haruldane kiriku-ja kalendripühadel lemmiklooma haual pits viina ja suutäis söödavat võtta. Toiduohvriga peetavat meeles ka loomade sünni- ja surmapäevi, samuti olevat muidugi vastavalt aastaajale - kombeks neil päevil keskmisest sagedamini lemmikute haudu korrastada, lilli tuua/istutada või muul viisil lahkunud neljajalgset sõpra meenutada.

Valga loomakalmistul pole senini kuuldavasti mingeid erilisi tseremooniaid loomade matmisel täheldatud. Ühishauda matmisel ajab traktor kalmistu tagumisse serva kraavi sisse. Sinna maetakse hulkuvad loomad ja ka enamik kodudes peetud lemmikuid. Pooleliolev ühishaud ei paku kahjuks esteetilist vaatepilti, eriti kevadisel lumesulamisajal. Kraavi täitudes ajab traktor jälle mulla peale, pinnas tasandatakse ja kogu tseremoonia eelkirjeldatuga piirdubki (Marju Torp-Kõivupuu intervjuud 2002. aasta suvel Jaan Luha ja Endel Rebasega ning ekspeditsioon kalmistule 2004. aasta kevadel). 


\section{Kalmistukultuur ja usundiline pärimus}

Mõne kalmistul puhkava lemmiku kohta teab T. Truumaa kõnelda ka usundilise pärimuse alla liigituvaid jutte. Kalmistuperemehe sõnutsi võib liigne lemmikule keskendumine mõjuda pärssivalt inimeste sigimisvõimele. Väidetavalt elanud vene rahvusest noorpaar neli-viis aastat koos, kuid järeltulijaid ei olnud ega tulnud. Ka meditsiin laiutanud käsi - noortel tervis kõigiti korras. Noorpaar kaalunud isegi kasulapse võtmist. Kuid siis surnud pere lemmik - kõuts Oskar -, kellele kuulunud senini kogu tähelepanu. Ja ennäe imet - mõni kuu pärast kassi matuseid jäi noorik käima peale ja sünnitas terve lapse (vt ka Lepassalu \& Palli 2000: 40).

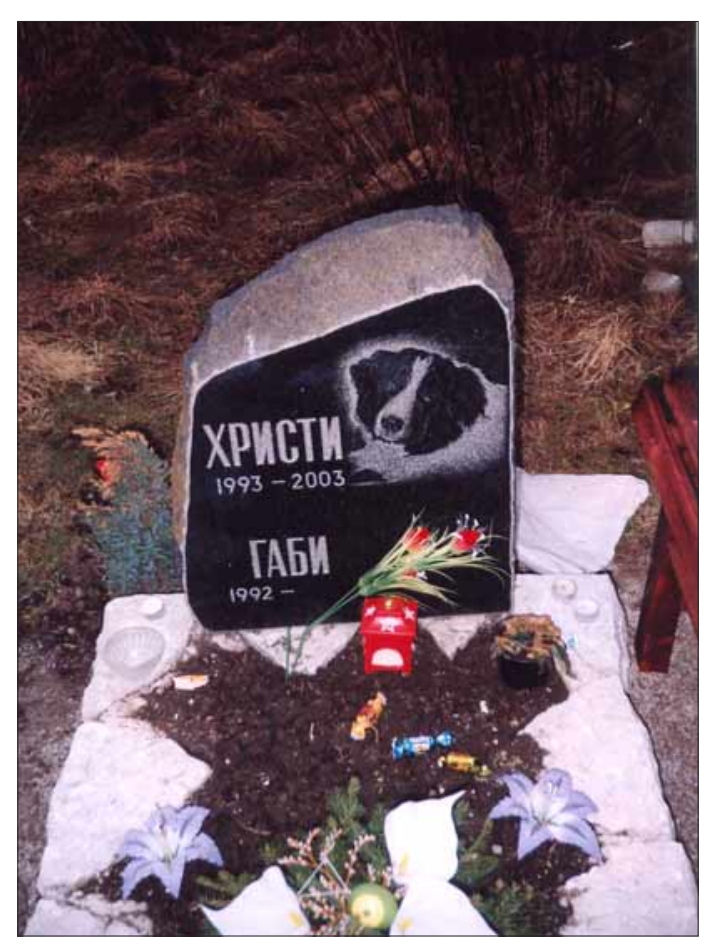

Foto 23. Kirikupühadel tuuakse ka lemmiku kalmule toidukraami. Marju Torp-Kõivupuu foto 2004. 


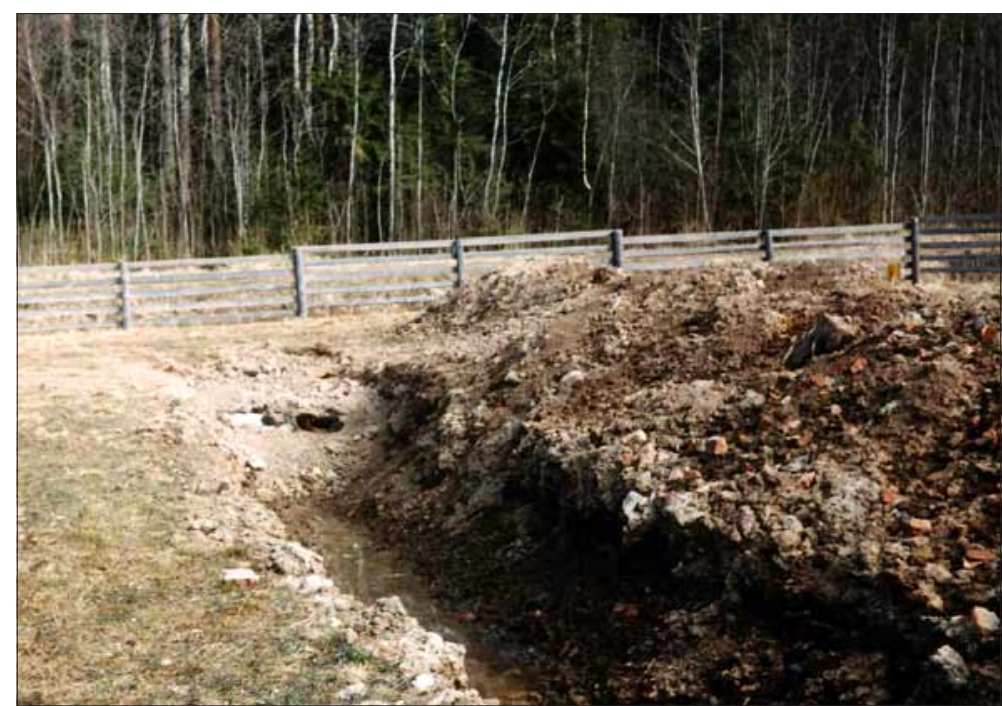

Foto 24. Ühishaud Valga loomakalmistul. Marju Torp-Kõivupuu foto 2004.

Teine koeraomanik on lasknud oma lemmiku hauale püstitada püramiidikujulise mustast graniidist hauasamba põhjendusega, et sammas kiirgab edasi kadunud koera positiivset energiat, mis aitab peremehel säilitada emotsionaalset tasakaalu ja head enesetunnet.

\section{Kokkuvõtteks}

Lemmikloomade matmistavade põhjal võib öelda, et antropomorfism pole suurele osale inimkonnale, sealhulgas ka Eestis elavatele lemmikloomapidajatele, tänapäeval võõras. Koduloomi on kujundatud inimese järgi, nagu jumal lõi inimese oma näo järgi. Inimene otsustab, kuidas lemmikut matta - kas kaevata talle lihtsalt auk või saata ta teise maailma orkestri saatel, tähistades tema matmispaiga hauakiviga. Looma samastamine inimesega räägib inimese väärtustest ja tema sisemaailmast, väidab psühholoog Voldemar Kolga ja tõstatab samas arvukalt küsimusi: Kas on ikka hea samastada looma inimesega? Kas looma ja inimese vahel ei ole mingit vahet? Kas koera käest on küsitud luba rõivastada teda nagu inimest, anda talle süüa nagu inimesele ja matta teda nagu inimest (Kolga 2000: 41)? 
Kuigi lemmikloomade matmispaikade praktilisest vajadusest linlikus kultuuriruumis saadakse tänapäeva Eesti ühiskonnas isegi aru, tekitab lemmikloomade kalmistukultuur siiski paljudes inimestes jätkuvalt võõristust ning seda eelkõige loomamatuste liigse luksuse ja toreduse pärast. Teades, et postsotsialistlikus Eestis jääb paljude inimeste, sealhulgas laste elukvaliteet (tõupaberitega) lemmikloomade omale alla ja mitte ainult eluheidikute, vaid ka n-ö tavaliste inimeste viimsele teekonnale saatmine ei toimu sageli ligilähedaseltki selliste austusavalduste saatel nagu tõukoerte ja -kasside puhul, on ilmselt seetõttu just lemmikloomakultuuri matusekombestiku osa põhjuseks, miks see nähtus on pälvinud pressi pigem iroonilise varjundiga tähelepanu: loomakalmistu teenuste kasutajatest kõneldakse kui veidratest klientidest, kellel on eluka(te)st kireobjektid jne (Lepassalu \& Palli 2000: 38, 40). Looma ja inimese matmisrituaali ja hauakultuse läbi võrdsustamise halvustamine kajastub ka seniilmunud artiklite pealkirjades või sisututvustustes (vt nt Luup võrdles koera ja inimese matuseid - Luubi esikaas, nr 10 (119), 15. mai 2000). Kahtlevat suhtumist loomakalmistu toetamisse tuli tõdeda omal ajal ka Harju Lions-klubi liikmetel:

Avamisel küll nuriseti, et ei tea, kas loomad väärivad nii suurt au. Kuid me ei jõua kõiki toetada (Lepassalu \& Palli 2000: 41).

V. Kolga teeb loomaomanikele ettepaneku näpistada midagi oma lemmiku eelarvest ja kanda see näiteks Inimliku Matmise Fondi (IMF) arvele, sest inimlik on seegi, kui ka inimene saab korralikult maetud (Kolga 2000: 41).

Teisalt peaksid neljajalgsete lemmikute matmise - sealjuures iseäranis luksusliku matmise - tavad olema ajaloost tuttavad: seda on rakendanud mitmed muistsed kõrgkultuurid, nii vanad egiptlased kui ka antiikrahvad.

Lemmikute matmiskombed ja -tavad kopeerivad Eestis - nagu ka mujal maailmas - suuresti inimeste matusekombestikku, mingeid erilisi uusi tavasid ega kombeid, mis oleksid iseloomulikud ainult ja ainult loomakalmistukultuurile, ei ole senini õnnestunud fikseerida.

Kui inimeste puhul kasutatakse surmast kõneldes eufemistlikke väljendeid (lahkus siitilmast, läks igaviku teele, jättis maha maised rajad, läks vaatama, kuidas kartul altpoolt kasvab jne), siis loomaomanikud kõnelevad looma surmast oma kujundikeeles - üks 


\section{Marju Torp-Kõivupuu}

või teine lemmikkutsu lahkub meie hulgast vikerkaare taha või vikerkaaremaale (Viivika Vares Marju Torp-Kõivupuule mais 2004). Kui meenutada eesti rahva vanu uskumusi vikerkaarest kui sillast elavate ja surnute maailma vahel, siis näib selle kujundi kasutamine olevat igati kohane.

Nõnda, nagu päevalehtedes avaldatakse surmateateid ja leinakuulutusi lähedase inimese lahkumise korral, ilmub kitsale ringile mõeldud looomaomanike ajakirjades (nt Eesti Kennelliidu ajakirjas Koer; Tartu lambakoerte kasvatajate ühingu ajakirjas Uran) koerte nekrolooge, surmakuulutusi ja kaastundeavaldusi omanikele neljajalgse sõbra kaotuse puhul (Viivika Vares Marju TorpKõivupuule mais 2004).

Uue tavana peeti 8. mail 2004 Jõelähtme loomakalmistul esimest korda kalmistupäeva, millele eelnesid samal hommikul talgud: kalmistu ja selle ümbruse korrastamine jm heakorratööd.

Kui võrrelda Eesti lemmikloomade kalmistukultuuri põhjanaabrite soomlaste omaga, leiame hulgaliselt sarnaseid kombeid ja tavasid (Hyttinin 1996), kuid ka mõndagi erinevat. Näiteks Eestis pole kombeks märkida hauatähisele loomaomaniku ega leinaja nime, kuid väidetavalt kohtab seda Helsingi loomakalmistu hauatähistel, mis Sonja Hyttise sõnutsi on tunnistuseks inimese ja lemmiklooma eriti tugevast vaimsest sidemest (Hyttinen 1996).

Kuigi lemmikloomade kalmude külastamine-korrastamine-ehtimine (kiriku)kalendritähtpäevadel on omane nii siin- kui ka sealpool Soome lahte, võib taas tõdeda, et erinevusi detailides leidub selleski vallas. Erinevalt soomlastest pole lihavõtete aegu kalmistul käimine ja kalmudele kevadlillede ja/või pajuurbade viimine eestlaste (teisisõnu - luterlaste) hulgas kuigi populaarne, see on pigem nn vene komme, mis kajastub ka Eesti loomakalmistukultuuris: õigeusklikest loomaomanikud viivad lihavõttepühadel ka oma lemmikute kalmudele värvilise muna, kompvekke, urvaoksi vms. Seda kommet järgitakse Jõelähtme loomakalmistul kohe kindlasti.

Loomakalmistu-ja surmakultuuri peamised erinevused eestlaste ja soomlaste vahel näivad põhinevatki peaasjalikult loomaomanike religioossetel tõekspidamistel: luterlastest loomaomanikud kannavad lemmikloomakultuuri üle oma tavad ja kombed, õigeusklikud omad. Kui tänapäeva postsotsialistlikus ja multikultuurilises Eesti ühiskonnas, kus religioon on paljudele pigem igand, minevikku kuuluv nähtus, arutatakse päevalehtedes tuliselt, kas lülitada religiooniõpetus koolide õppekavadesse või mitte, siis näiteks 


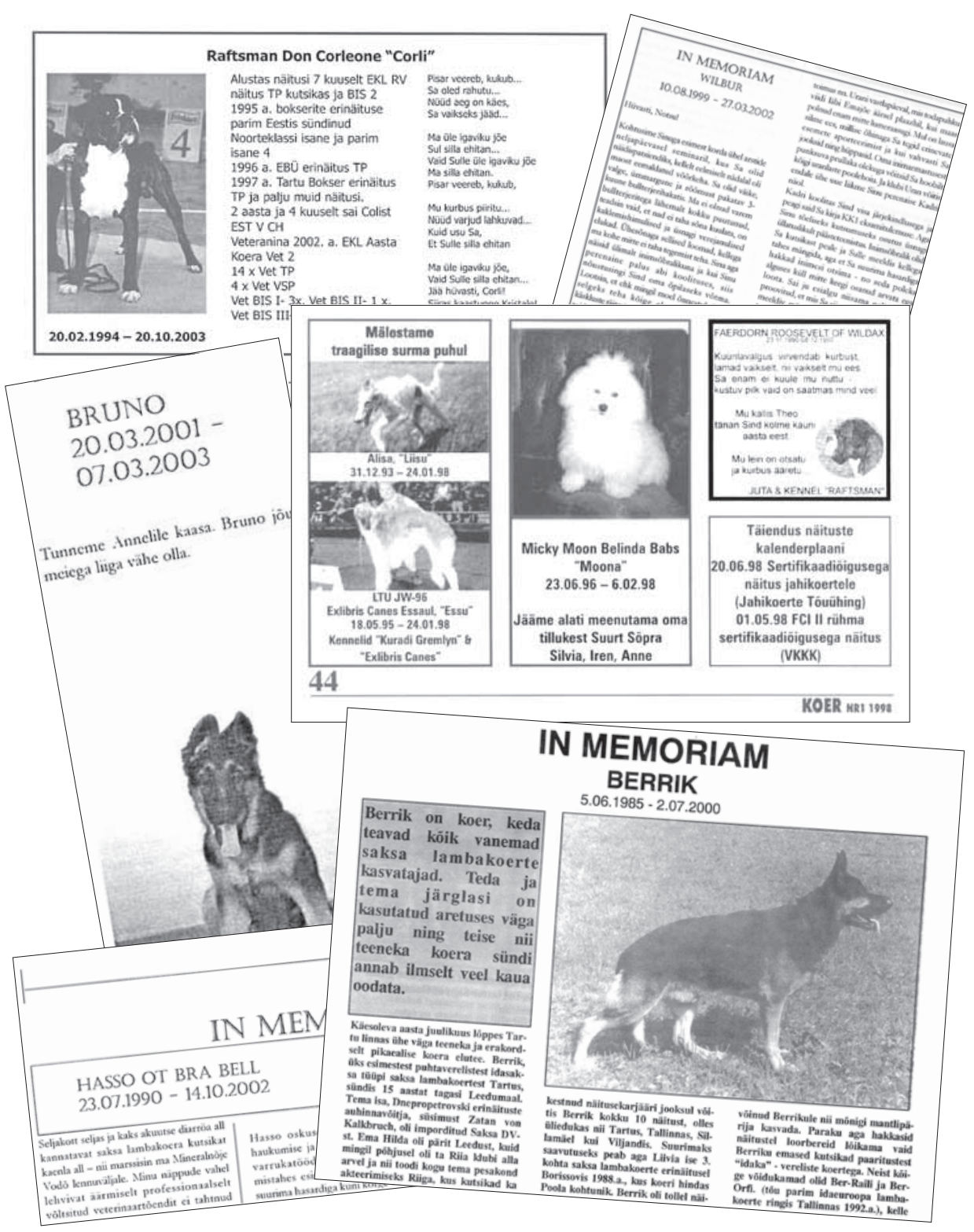

Foto 25. Näiteid kaastundeavaldustest lemmiklooma kaotuse puhul ja koerte nekroloogidest (Koer 1998, nr 1: 44, 2003, nr 4: 23; Uran 2000, nr 2: 21, 2002, nr 1: 14, nr 3: 11). 


\section{Marju Torp-Kõivupuu}

1992. aastal tekkis Helsingi kirjutavas meedias diskussioon teemal "Kas (lemmik)loomad pääsevad taevasse või ei?" (vt Hyttinen 1996).

Kuid hoolimata sellest, et loomaomanikud jäljendavad nii siinkui ka sealpool Soome lahte (ja tõenäoliselt mujalgi Euroopas) lemmikute matusekombestikus ja kalmistukultuuris oma religioosseid tõekspidamisi, ei kuulu need tavad ja kombed siiski kristliku pärimuse hulka.

Kahjuks puuduvad ka tänapäevased sotsiaalpsühholoogilised ja etnoloogilised uurimused Eesti lemmikloomapidajate rahvusliku kuuluvuse, haridustaseme, usuliste tõekspidamiste, elamistingimuste, elatustaseme, loomadega seonduva pärimusmaterjali, kodus peetavate loomaliikide jne kohta, et teha sügavamaid üldistusi. Suhteliselt napi kogutud ainese põhjal julgen väita, et lemmiklooma(kalmistu)kultuur on enam arenenud Eesti mitte-eestlastest elanikkonna hulgas, kellel - vastupidiselt eestlastele - puudub traditsiooniline külakultuur ja kelle kontsentratsioon on suurem (tööstus)linnades.

Väikeloomade kalmistuid on Eestis ametlikus korras tekkinud juurde, järelikult on inimestel vajadus nende järele mitte ainult suuremates, vaid ka väiksemates nn maa-asula tüüpi linnades, kus elavad enamikus eestlased. See on ka mõistetav, sest lemmikute eluiga on omanike omast reeglina oluliselt lühem ${ }^{1}$ ja pärast surma vajab peresse võetud lemmikloom väärikat kohtlemist. Psühholoogid soovitavad lastega peresse võtta lemmikloom, et lapsest kasvaks emotsionaalselt täisväärtuslik inimene, et ta õpiks maastmadalast tundma ning kogema elu ja surma igavest ringkäiku. Kahte surma pole kellelgi ja ühest ükski ei pääse, ütleb vanasõna.

Autor tänab suuliste teadete eest Viivika Varest ja Ell Vahtramäed.

\section{Kommentaar}

${ }^{1}$ Veterinaar Tiit Truumaa sõnul on linnaloomade (koerte-kasside) eluiga sageli vastava loomaliigi keskmisest elueast lühem, paiguti kõigest 4-5 aastat: linna stressirohke elu mõjub ka loomadele kurnavalt.

\section{Intervjuud}

Truumaa, Tiit 2001. Intervjuu Marju Torp-Kõivupuule. August.

Truumaa, Tiit 2002. Intervjuu Marju Torp-Kõivupuule. Jaanuar. 


\section{Marju Torp-Kõivupuu}

Luht, Jaan [Valga Veterinaaramet] 2002. Intervjuu Marju Torp-Kõivupuule. 5. juuli.

Rebane, Endel [Valga linnavalituse linnahooldusamet] 2002. Intervjuu Marju Torp-Kõivupuule. 5. juuli.

Vahtramäe, Ell 2004. Suulised teated Marju Torp-Kõivupuule.

Vares, Viivika 2004. Intervjuu Marju Torp-Kõivupuule. Mai.

\section{Kirjandus}

Ariès, Philippe 1977. L'homme devant la mort. Paris: Seuil.

Hyttinen, Sonja 1996. "Muisto elää!”: Lemmikeläimen kuolema ja hautamuistomerkit Helsingin eläinten hautausmaalla. Eeva-Liisa Kinnunen \& Kaarina Koski \& Riikka Penttilä \& Minttu Pietilä (toim). Vitsistä videoon: Uusia kirjoituksia nykyperinteestä. Tietolipas 146. Helsinki: Suomalaisen Kirjallisuuden Seura, lk 137-155.

Jobes, Gertrude 1962. Dictionary of Mythology, Folklore and Symbols. New York: Scarecrow Press.

Kiiler, Gert 2002. Rakvere lemmikloomakalmistul puhkavad kõrvuti krants ja tõukoer. Sakala, 16. august (vt ka http://vana.www.sakala.ajaleht. ee/index.html?op=lugu\&rubriik=52\&id=3390\&number=169 -15 . mai 2004).

Koer: Eesti Kennelliidu väljaanne 1998, nr 1; 2003, nr 4.

Kolga, Voldemar 2000. Inimeseloomad: Kommentaar [V. Lepassalu ja I. Palli artiklile "Olgu muld sulle kerge: Kadunukesed: Eestis maetakse mõningaid loomi nagu inimesi ja inimesi nagu loomi”]. Luup 10 (119), 15. mai, lk 41.

Kruus, Tiina 2004. Minu pere ja muud loomad. Eesti Naine 4 (aprill), lk 32-35 (vt ka http://www.eestinaine.ee/40707 - 14. aprill 2004).

Kuulsaid mõisnikke = Harjumaa mõisad . Kuulsaid mõisnikke. Nikolai von Glehn (http://www.muuseum.harju.ee/Moisad/kuulsaid/kuulsaid_ glehn_02.html - 27. mai 2004).

Lepassalu, Virko \& Palli, Ilmar 2000. Olgu muld sulle kerge. Kadunukesed. Eestis maetakse mõningaid loomi nagu inimesi ja inimesi nagu loomi. Luup 10 (119), 15. mai, lk 38-41.

Lindgren, Astrid 1969, 1993, 2000. Väike Tjorven, Pootsman ja Mooses. Tõlk Vladimir Beekman. Tallinn: Eesti Raamat.

Loorits, Oskar 1990. Eesti rahvausundi maailmavaade. Tallinn: Perioodika.

Läänemaa. Everyday.com e-kaart. Teemagalerii. Eesti erinevad paigad (vt http://www./ekaart/Laanemaa.html - 27. mai 2004). 


\section{Marju Torp-Kõivupuu}

Mikkor, Marika 2000. Minu merisigade elust. Mäetagused 15, lk 152-158 (vt ka http://haldjas.folklore.ee/tagused/nr15/mikkor.htm).

Nerman, Robert 1998. Lasnamäe ajalugu. Tallinn: Eesti Entsüklopeediakirjastus.

Olvet, Triin 1999. Loomakalmistu aitab hoida mälestust neljajalgsest sõbrast. Postimees, 26. juuli.

Pentikäinen, Juha 1990. Suomalaisen lähtö: Kirjoituksia pohjoisesta kuolemankulttuurista. Suomalaisen Kirjallisuuden Seuran toimituksia 350. Helsinki: Suomalaisen Kirjallisuuden Seura.

Päärt, Villu 2004. Surnukuur küsis raha põrmu väljastamine eest. Postimees, 15. aprill.

Stark, Tuula 1993. Pet Cemetry: "We'll take the Rose Now Between Her Paws and thus We'll Open the Heaven's Doors.” Käsikiri: Helsingi Ülikool, rahvaluule õppetool.

Suviste, Maarius 2000. Kilpkonna peab matma nagu inimest. Maaleht, 18. mai.

Torp-Kõivupuu, Marju 2003. Surmakultuuri muutumine ajas: Ajaloolise Võrumaa matusekombestiku näitel. Monograafia. TPÜ Toimetised. Humaniora A 22. Tallinn: Tallinna Pedagoogikaülikool.

Uran: Tartu Saksa Lambakoerte Klubi ajakiri 2000, nr 2; 2002, nr 1, 3.

Varjupaigad (http://www.eau.ee/ astan/varjup.htm\#varjup - 15. mai 2004).

Vesik, Liisa 2003. Saak 2003: Ristirotid: Suhteid ühes yahoo.com suhtlusgrupis. Ettekanne Akadeemilise Rahvaluule Seltsi kogumiskonverentsil 30. oktoobril.

Viljandimaa Turismiinfokeskus (http://www.viljandimaa.ee/turismiinfo/ ?mod=9\&sort=1\&id=114\&pknd $=-27$. mai 2004).

Wiedenmann, Rainer E. 1993. Neuer Totemismus? Überlegungen zur Genese und Semantik moderner Tierbestattung. Soziale Welt 44: 2, lk 199222.

Wolf, Michèle 1989. Tierfriedhöfe in Frankreich. Zeitschrift für Semiotik 11: 2/3 (vt teesid: http://ling.kgw.tu-berlin.de/semiotik/deutsch/ZFS/ Zfs89_2.htm\#wolf - 15. mai 2004). 